\title{
Lirismo no debate epistolar modernista
}

\author{
Marcia Regina Jaschke Machado \\ Doutora em Literatura Brasileira pela USP
}

\begin{abstract}
Resumo: A troca de cartas entre os modernistas brasileiros fez circular textos inéditos e debates teóricos sobre a produção literária moderna, produzindo redes de sociabilidade letrada e consensos estéticos e politicos. Este artigo tem por objetivo o estudo do tema lirismo discutido na correspondência de Mário de Andrade com alguns de seus interlocutores durante os anos de 1920.

Palavras-chave: Lirismo, Modernismo brasileiro, Epistolografia.
\end{abstract}

A tentativa de definição de "lirismo" na poesia modernista foi uma das principais ações de alguns escritores brasileiros que propuseram a renovação literária no início do século XX. "Lirismo", para escritores modernistas nos primeiros anos da década de 1920, passou a representar liberdade de invenção literária e, consequentemente, o recurso fundamental de crítica à estética parnasiana, que ainda no início dessa década imperava sobre o gosto dos leitores.

1 Este artigo se desdobra da tese de doutoramento de minha autoria, O Modernismo dá as cartas: circulação de manuscritos e produção de consensos na correspondência de intelectuais nos anos de 1920, que contou com o apoio do CNPq. 
Era, contudo, um parnasianismo tardio, em que a composição de poemas havia se tornado mero cumprimento de regras extremamente rígidas. Como observa Roberto Schwarz: "A mania formalizante que reinou pelos inícios do século, sustentada pelos que então eram mestres, levou à atrofia de seu próprio conceito fundamental: de interior a forma passou a ser puramente exterior, deixou de enformar para vestir."

Como questão crucial para aqueles que se mobilizavam para formar um novo movimento literário, explanações sobre "lirismo" são frequentes nos estudos da época; ao mesmo tempo, ele era muito debatido nas correspondências de vários intelectuais. Nesse sentido, Mário de Andrade assumiu um papel pioneiro no debate e difusão de seus posicionamentos sobre esse tema. Era urgente que alguém tomasse a frente das inovações que colocassem fim às condições da poesia parnasiana.

Em estudo fundamental sobre a poética de Mário de Andrade, Roberto Schwarz observa três etapas na conceituação de "lirismo" formuladas pelo escritor ao longo de sua trajetória intelectual:

$1-$ momento individualista, poesia $=$ grafia do subconsciente (lirismo), com um mínimo de interferência técnica; 2 - momento antiindividualista; poesia $=$ grafia do subconsciente transformado em arte e tornado socialmente significativo pela interferência técnica; o lirismo individual pode mesmo desaparecer em favor de uma fonte de emoção coletiva, o folclore; a valorização está toda no preparo técnico e cultural que permitirá a realização da tarefa nacionalista; 3 - superação dos momentos anteriores, que desponta no conceito de técnica pessoal, em que um lirismo específico (subconsciente individual) encontra uma técnica (nível consciente) capaz de realizá-lo no plano do significado geral. ${ }^{3}$

Essas transformações de perspectiva de Mário de Andrade estão registradas ao longo de toda sua obra, a partir do "Prefácio interessantíssimo", de Pauliceia desvairada, bem como em sua correspondência. Neste trabalho, serão tratados apenas os dois primeiros momentos. Essas transformações, que vão de um extremo individualismo à necessidade de se fazer entender pelo leitor, quando sua produção assume cunho sociologizante - a que denomina

2 SCHWARZ. A sereia e o desconfiado, p. 14. Grifos do autor.

3 SCHWARZ. A sereia e o desconfiado, p. 15. Grifos do autor. 
arte-ação -, estão marcadas por uma grande angústia de definição teórica por parte do autor. Angústia que foi extremamente debatida por cartas com seus interlocutores, principalmente com Manuel Bandeira.

Desse modo, os estudos e editoriais-manifestos das revistas modernistas publicados na época, tanto por Mário de Andrade quanto por aqueles que sentiam a necessidade de definir teoricamente as inovações propostas, mostram o quanto esse tema era importante para eles. Entretanto, esses textos expõem as formulações já elaboradas para irem a público. Quando passamos a ler as correspondências trocadas entre os intelectuais modernistas, deparamo-nos com essas formulações em processo de reflexão. Se os textos publicados apresentam posicionamentos determinados, as cartas mostram a elaboração desses posicionamentos, que será aqui denominada de "crítica informal" ", justamente por seu caráter privado. São as discussões presentes nas missivas modernistas que nos interessam.

Como na maioria dos seus questionamentos teóricos, foi Manuel Bandeira o grande interlocutor de Mário de Andrade sobre suas formulações a respeito do "lirismo". Quando Bandeira recebeu seu exemplar de Pauliceia desvairada, redigiu longa carta com suas impressões sobre os "poemas tão belos e tão estranhos". Nela, apesar de afirmar que Pauliceia desvairada era para ele o livro mais moderno que fora publicado até então no Brasil, Bandeira aponta seu estranhamento em relação a alguns excessos, como o "desvairismo gongórico", certos neologismos, a grande quantidade de rimas e ecos internos. $\mathrm{Na}$ resposta a esses comentários, Mário assumiu e explicou seus excessos:

4 É preciso que haja um esclarecimento sobre esta fórmula, uma vez que a palavra "informal" não implica um modo indefinido para essa prática, muito pelo contrário; tão pouco que a crítica fosse pouco elaborada, pois é o oposto que se verifica em textos muito bem refletidos. A fórmula diz respeito, unicamente, à situação em que tal crítica era produzida, na qual os interlocutores sentiam-se muito mais à vontade para se posicionarem, mesmo que suas ideias rendessem a censura do destinatário da missiva.

5 ANDRADE; BANDEIRA. Correspondência Mário de Andrade E Manuel Bandeira, p. 69. Carta a Mário de Andrade, de 3 de outubro de 1922, em que Manuel Bandeira tece comentários ao recém-publicado Pauliceia desvairada.

6 ANDRADE; BANDEIRA. Correspondência Mário de Andrade E Manuel Bandeira, p. 69. 
Há exageros na minha obra. É verdade muito minha. Se te não disse ainda, digo-te agora a razão por que os conservei. Trata-se duma época toda especial de minha vida. Paulicéia é a cristalização de 20 meses de dúvidas, de sofrimentos, de cóleras. É uma bomba. Arrebentou. Era preciso que arrebentasse, senão eu me estiolaria no toda-a-gente porco, vilíssimo de X..., de Y.... de... de... (põe aqui todos os nomes desses infelizes que são poetas, não há negar, mas que o não sabem ser). [...] Zangaste com o verso alexandrino e parnasiano "e o ciúme universal etc." Mas, caro Manuel, sabes da liberdade, mesmo excessiva que há no meu livro: portanto não foi preconceito que me obrigou àquela fórmula. Era assim mesmo. Senti assim. Saiu assim. Como posso eu desritmar um movimento que brotou naturalmente? Só por prevenção? Mas no "Prefácio" já afirmava não desdenhar balouço de versos comuns. A comoção muita vez está num ritmo comum. Os ritmos comuns existiram primeiro na natureza, depois no preconceito. Não há preconceito nem chavão que não tenha existido naturalmente. E o meu ocasional alexandrino, mesmo com seus dois substantivos e dois adjetivos, existiu ali naturalmente dentro de mim. Da mesma forma rimas e metros que dentro do livro se encontram. Além disso eu estava muito perto do meu passado. Esta lei de hímen que nos persegue!

Nessa passagem, em primeiro lugar, Mário expressa o quanto era urgente apresentar uma poesia que revitalizasse a produção literária brasileira - "era preciso que arrebentasse" - em oposição aos poetas que "não o sabiam ser”, em alusão muito provável aos parnasianos. Além disso, ele se defende quanto ao emprego de alguns versos alexandrinos, justificando-se pela liberdade que os modernistas anunciavam de transpor o impulso lírico para o poema em respeito ao modo como ele se constituía no subconsciente. No "Prefácio interessantíssimo", cabe lembrar, explica também essa posição. Ainda nessa missiva, Mário já anunciava a redação de novos trabalhos, Losango cáqui e "A escrava que não é Isaura”:

Fiz uma espécie de diário em verso do meu tempo de serviço militar. Está engraçado. É possível que o publique. São pequenos momentos de minha vida. Dirão que é romantismo. Mas não há poeta nenhum verdadeiro que

7 ANDRADE; BANDEIRA. Correspondência Mário de Andrade E Manuel Bandeira, p. 72. Carta com data atestada de outubro de 1922. 
não tenha em seus versos pequenos momentos de vida. Serão demasiado pessoais. São como os livros da vida. A minha obra mais universal, mais humana, virá mais tarde. Antes porém (até dezembro) publicarei um rápido estudo sobre a poesia modernista: A Escrava que não é Isaura. Quero ver se esclareço um pouco a compreensão da gente que lê. Ao menos saberão que não estão lendo loucos.

Nesse momento, Mário ainda não manifestava angústia em relação ao caráter subjetivo de seus poemas, fato que ocorreria em breve e que despertaria sua defesa da "arte-de-ação". Entretanto, pode-se perceber que ele já se preocupava com essa questão e que já pretendia elaborar uma poesia de cunho menos pessoal. Ao mesmo tempo, dava indícios de preocupação com o leitor, pois entendia o quanto era necessário tornar a nova produção mais aprazível, com a finalidade de conquistar um público para esses textos.

A resposta de Manuel Bandeira, por sua vez, esclarece bem o seu posicionamento diante das inovações modernistas. De acordo com a postura, que assumiu durante toda a sua vida, preferiu uma atitude não tão extremada no que se refere à relação entre impulso lírico e sua elaboração pela técnica.

Tens toda razão no que dizes sobre versos alexandrinos. Sentiste assim. Mas quando a gente sente com força, com exagero, mete às vezes os pés pelas mãos. A inteligência às vezes intervém e pondera: isso não.

Eu faço muitos alexandrinos daqueles de substantivo e adjetivo e vou publicá-los: são versos da alma passadista, à qual é delicioso sorrir como às lindas senhoras envelhecidas... Mas aquele alexandrino e aquelas rimas na Paulicéia e talvez no lugar onde estão me desagradam. 'Mas a emoção pedia assim!' A tua emoção me irrita. E pronto: sentimento contra sentimento. Não há nada a fazer.

Mário, meu querido Mário: somos sinceros. Nunca me passou pela cabeça que tenhas querido fazer obra extravagante, que tenhas procurado criar alexandrinos, etc. Tudo o que fizeste, fizeste com espontaneidade. Acredita agora também que as minhas observações nasceram não de preconceitos modernistas, mas de idiossincrasias irremediáveis. Nem pretendo ter razão.

8 ANDRADE; BANDEIRA. Correspondência Mário de Andrade G Manuel Bandeira, p. $72-73$.

9 ANDRADE; BANDEIRA. Correspondência Mário de Andrade E Manuel Bandeira, p. 74 . Carta com data de outubro de 1922. 
Esse prudente interlocutor dispunha-se sempre a refletir sobre as inovações modernistas. Defendia que elas ocorressem sem exageros, por meio de elaborações muito bem estruturadas. Mesmo tendo se formado nos moldes parnasianos, com muitos dos poemas dos seus primeiros livros ainda seguindo essa corrente - A cinza das horas, Carnaval e O ritmo dissoluto -, Bandeira identificava-se com a urgência de renovação da intelligentsia brasileira. Entretanto, observa-se sua postura menos radical que outros, como o próprio Mário de Andrade ou Oswald de Andrade, por exemplo. No trecho da carta transcrito acima, ele não nega radicalmente a interferência da "inteligência" (consciência) no processo de transposição do impulso lírico ao poema. Ao contrário, ele a aceitava como instrumento de escolha do que realmente valeria ser transformado em poema. E isso incluía aceitar regras utilizadas pelos parnasianos, desde que de forma consciente.

De qualquer modo, a preocupação de Mário de Andrade com o caráter demasiado pessoal dos seus poemas de Losango cáqui não foi enfatizada na carta de outubro de 1922, parecendo até uma questão pouco relevante. Entretanto, na medida em que ele foi reformulando seu conceito de "lirismo", essa preocupação avultou. É o que se pode verificar tanto na "Advertência" de Losango cáqui, quanto nas cartas de Mário de Andrade para seus interlocutores.

Em seu livro de poemas seguinte, Clã do jabuti, Mário de Andrade encontrava-se já no segundo momento de conceituação de "lirismo", apontado por Roberto Schwarz. Abordagens desse tema acompanharam seus diálogos com Manuel Bandeira sobre os manuscritos que começou a lhe enviar, enquanto projeto de livro, efetivamente, na carta de 7 de abril de 1924. Antes disso, Mário já havia remetido esparsamente poemas que fariam parte desse livro. É importante reiterar que a publicação de Clã do jabuti aconteceria somente em 1927.

No ano de 1924, Mário de Andrade trabalhou intensamente na elaboração dos poemas de Clã do jabuti. Manuscritos dessa obra circularam entre ele e Bandeira; este, expondo suas opiniões e sugerindo alterações; aquele, acatando muitas delas, mas outras não. Um exemplo disso está na longa carta de 7 de novembro de 1924, em que Mário, entre respostas a argumentações de Bandeira, rebate seus comentários sobre verso livre no poema "Noturno de Belo Horizonte", em processo de composição: 
"O Sr. Barão das Catas Altas

Reúne todas as constelações

Pra fundir uma baixela de mundos."

Queres que eu faça disso um só verso. Não há razão propriamente. Ao contrário. Se por acaso no verso livre cada verso correspondesse a um juízo inteiro, então terias razão, mas o verso livre não é só isso, embora seja também isso. Há muitas vezes que obedecer a ritmos interiores pessoais. E geralmente isso obedece a intenções que podem transparecer embora não conscientes no momento primeiro da escritura. O "Sr. Barão das Catas Altas", sozinho, ressalta na importância cômica que lhe dou. A frase tripartida ressalta assim na importância que lhe dou, um pouco irônica a princípio e terminando incisiva, brilhante, visionária, eloqüente, no rápido "pra fundir uma baixela de mundos" que tem de vir livre, sozinho como um rojão em céu escuro. Repara como esse verso é rápido, muito mais rápido que os dois anteriores, embora com maior número de sílabas. Mistérios da Idéia, amigo!... E repara o vigor do meu "pra” em comparação ao quilométrico e incolor "para".

Bandeira redigiu a resposta a essa longa carta em 20 de novembro de $1924^{11}:$

Recebi esta tarde a tua carta de 7. Tomaste muito à conta de correções o que fui lançando rapidamente à margem dos teus poemas. Aquilo tudo eram apenas sugestões. Não pude explicar porque seria um não acabar de escrever, o que me cansa muito. [...] Fique o "barão das Catas Altas" sozinho. Mas não penses que eu tenha nunca tomado o verso livre só como a expressão de um juízo inteiro.

$\mathrm{Na}$ edição final de Clã do jabuti, os versos foram conservados separadamente. Sobre lirismo, contudo, cabe destacar a missiva que Mário enviou

10 ANDRADE; BANDEIRA. Correspondência Mário de Andrade E Manuel Bandeira, p. 144.

11 Vale destacar que a troca de cartas entre eles nesse período era muito intensa. Mário de Andrade, inclusive, faz pilhéria sobre isso: "Nós andamos numa carteação danada, puxa! É carta pra cá, carta pra lá, até parece noivado.” (ANDRADE; BANDEIRA. Correspondência Mário de Andrade E Manuel Bandeira, p. 153. Carta a Manuel Bandeira, com data atestada de 22 de novembro de 1924).

12 ANDRADE; BANDEIRA. Correspondência Mário de Andrade E Manuel Bandeira, p. 150. 
em 19 de novembro de 1924, antes de receber a resposta a sua carta anterior, de 7 de novembro, comentando poema inédito que recebera de Bandeira - enviavam, simultaneamente, seus textos um ao outro. Ainda sem título, o poema que posteriormente seria nomeado "Comentário musical", para constar em Libertinagem, fora remetido no corpo da carta de 16 de novembro de 1924.

Me parece no entanto que o poema precisa de mais um verso. Está bom como está. Acaba tão natural. Aquele último verso dito indiferentemente, olhando pro lado, ou coçando a perna, é estupendo de naturalidade. Mas vem a dar naquela discussão comigo, que expus no prefácio do Losango cáqui. É lirismo puro. A poesia se ressente porque falta a intenção-depoema, isto é, a intenção de fazer um poema, que é uma peça de arte, peça inteira, fechada, com princípio, meio e fim. O teu poema não acaba. E pra ser poema precisa acabar. Carece não confundir lirismo e poesia. É o grande passo que já dei do Losango pro Clan do jabuti. Arte simples ainda. Primitiva, apesar de todas as ilusões do Graça. Mas atualmente escrevo poemas. Escrevo arte. Faço arte.

Mário de Andrade reforça nessa carta seu momento de transição na conceituação de "lirismo". Reitera no final desse trecho a relação entre "fazer poema" e "fazer arte", o que pode muito bem reportar ao que formulou em "A escrava que não é Isaura" ao refazer a fórmula de Dermée, conferindo à arte o sentido de "crítica, esteticismo, trabalho". Para Mário, o verso de Bandeira ficara solto, sem concluir o poema, por isso chamou a atenção do amigo para que o trabalhasse mais, não o deixando excessivamente lírico.

No mesmo mês de intensa troca epistolar com Manuel Bandeira, Mário de Andrade estava também se correspondendo com Carlos Drummond de Andrade. Acompanhando a carta de 22 de novembro de 1924, a segunda que lhe chegava desse recente interlocutor mineiro, Mário recebeu o manuscrito que fazia parte do projeto de livro Minha terra tem palmeiras e no qual estavam: "Política", "Construção", "Religião", "Nota social", "Sentimental", "Orozimbo" e "Passa uma aleijadinha". Fazia parte desse projeto grande parte dos poemas que, somente em 1930, seriam publicados em Alguma poesia. No término da

13 ANDRADE; BANDEIRA. Correspondência Mário de Andrade G Manuel Bandeira, p. 150.

14 ANDRADE. A escrava que não é Isaura, p. 205. 
longa resposta, Mário de Andrade redigiu algumas impressões sobre eles. Entre as observações de Mário, nessa carta, está sua opinião a respeito de "lirismo":

No Minha terra tem palmeiras, nome admirabilíssimo que eu invejo, há poemas excelentes e muita coisa boa. Mas como você ainda está muito inteligente de cabeça pra cair no lirismo, repare que há muita coisa que é contado [sic] com memória em vez de vivido com sensação evocada. Disso um qual ou tal elemento prosaico que diminui a variedade do verso livre porque o confunde com a prosa. Todos nós temos isso. Eu tomei o partido de escrever em prosa simplesmente, no meio dos versos, como aquele comentário inteligente (= da inteligência) que vem nas "Danças", ou o caso do coronel Leitão do "Noturno". Ou então metrifico ("Rola-Moça") pra não cair no verso prosaico. Metrificação ingênua, balbuciante primitiva, lírica. ${ }^{15}$

Drummond elaborou uma extensa resposta que toca no tema do "lirismo" ao comentar o poema de Mário: "Recebi o 'Noturno de Belo Horizonte', seguramente o maior esforço da poesia nacional. [...] suas idéias nacionalistas o conduziram de maneira lógica a um poema tão rico de expressão e intenção, em que o sentimento da terra se confunde com o mais puro e desinteressado lirismo".

Outro mineiro com quem Mário começou a se corresponder no ano subsequente, 1925, foi Pedro Nava. Para Mário de Andrade, ele enviou os poemas "Aterrissage", "Reflexos", o conjunto de dois poemas ("Bão-ba-la-lão" e "Nôite de são joão") que levou o título de "Cantares da infância", todos de 1925; "Noturno de Chopin", "Ventania", "Si eu soubesse brincar...", de 1926; "Prelúdio número um", segunda versão de "Si eu soubesse brincar...", de $1927 .{ }^{17}$

Da "crítica informal" que Mário de Andrade elaborou sobre os poemas de Pedro Nava, será apresentada a que se encontra na longa carta de 9 de março de 1925. Ela foi emitida em resposta à que o jovem mineiro redigira

15 ANDRADE; ANDRADE. Carlos \& Mário: Correspondência completa entre Carlos Drummond de Andrade e Mário de Andrade, p. 72. Carta s/d., certamente posterior a 22 de novembro e anterior a 30 de dezembro de 1924 .

16 ANDRADE; ANDRADE. Carlos \& Mário: Correspondência completa entre Carlos Drummond de Andrade e Mário de Andrade, p. 77. Carta de 30 de dezembro de 1924.

17 Esses manuscritos integram hoje o arquivo de Mário de Andrade no Instituto de Estudos Brasileiros da Universidade de São Paulo. Sobre eles, ver MACHADO, Manuscritos de outros escritores no arquivo Mário de Andrade: perspectivas de estudo. 
em 17 de fevereiro de 1925, na qual anexou os manuscritos de "Aterrissage" e "Reflexos". Mário, em sua resposta, pede que Nava redija por carta sua apreciação crítica de "A escrava que não é Isaura" e o adverte:

Em todo caso tome cuidado com ela [inteligência], heim! Depois que publiquei o livro [ E Escrava que não é Isaura] comecei a matutar que ele é perigoso. Pra você nem tanto que já deve estar lido e relido de coisas modernistas européias, mas pros outros que nada puderam ler e que se vão envenenar com a Escrava.

Além de manifestar sua preocupação com a recepção de seus conceitos sobre poesia modernista, Mário adverte o jovem sobre o uso da "inteligência", o que podemos interpretar, seguindo o próprio raciocínio estruturado em suas poéticas, que Mário se refere ao estado consciente que se sobrepõe ao inconsciente. Essa proposição é desenvolvida no extenso comentário sobre os dois poemas de Pedro Nava, quando Mário expõe sua opinião sobre "lirismo":

Eu vejo nos seus versos principalmente um grande perigo, Nava. Você está, ao menos nos 2 poemas que me mandou, se preocupando muito com a realização formal de certos aspectos fenomenais (fenomênicos quero dizer) do mundo exterior. Que tem lirismo eu sei. Um lirismo inicial até muito fino e bem bom. Eu também sempre me comovi com uma pedra que rola da montanha. [...] O lirismo inicial existe nos poemas que você me mandou e está muito bem exprimido, comoventemente no Aterrissage. [...] em vez de você se deixar levar pelo estado lírico em que o fato da pedra rolar do morro ou cair no poço botou você, você se preocupou mais com o processo com que ia realizar o fato exterior em vez de observar o seu estado psicológico e por ele descrever o fato exterior. Que aconteceu? Em vez dos processos técnicos, síntese, onomatopéias, superposição simultânea de palavras, combinações orais, em vez dos processos técnicos serem um meio pra você realizar a sua sensação e comoção (fim da Poesia, destino dela) foi uma certa sensação que você escolheu pra poder empregar e mostrar certos processos técnicos modernos. Assim pra você, ao menos nestes 2 poemas, a sensação é um meio, o processo técnico é o fim, a preocupação não direi exclusiva mas conclusiva da sua maneira de 
poetar. [...] O que eu tenho medo é que você fique nisso e só e comece a escolher dentre as sensações de você as que milhor se prestam pra certas demonstrações ou emprego legítimo de certas realizações processuais da poética modernista. Muito cuidado, Nava, em não confundir poética com poesia [...]. ${ }^{19}$

Mário salienta bem a relação entre lirismo e técnica de que Nava se valeu para compor seus poemas. Para ele, o jovem estaria mais preocupado em fazer poemas que formalmente se enquadrassem na poesia modernista do que em partir do seu impulso lírico para compô-los; não estaria utilizando a técnica para dar forma ao lirismo, mas, ao contrário, o lirismo estava lhe servindo de desculpa para realizar poemas com aspectos modernistas. Veja-se que Mário não negou a utilização da técnica, mas especificou sua função, a de instrumento de expressão do lirismo. No final de seus comentários, justifica sua postura:

Nunca se esqueça desta verdade geral: no fundo a poesia é uma só e continua a ser tradicional, seguindo a linha comprida que do homem da caverna vem até nós. Os progressos da experiência só nos permitiram reagir contra o mau caminho do parnasianismo e do simbolismo que desvirtuaram a poesia um tomando o lirismo como um meio, outro camuflando-o em enigmas mais ou menos bonitos. Permitiram com que nos aproximássemos mais do lirismo puro e enriqueceram os nossos meios de expressão.

Na resposta de Pedro Nava, de 3 de julho de $1925^{21}$, há apenas um breve parecer aos seus comentários, onde o jovem diz concordar com tudo, prometendo corrigir-se.

Em carta a Carlos Drummond de Andrade, de 26 de outubro de 1925, Mário falou sobre Pedro Nava: "De primeiro [Pedro Nava] me mandou uns poemas em que a rebusca de forma prevalecia sobre a qualidade lírica. Chamei a atenção dele sobre isso. Faz pouco me mandou dois poemas ${ }^{22}$ positivamente

19 ANDRADE. Correspondente contumaz, p. 38-40.

20 ANDRADE. Correspondente contumaz, p. 40-41.

21 Essa carta encontra-se no Instituto de Estudos Brasileiros da Universidade de São Paulo, Arquivo Mário de Andrade, série Correspondências, sub-série Correspondência Passiva (MA-C-CPL, 5414).

22 Mário de Andrade refere-se, provavelmente, ao conjunto de poemas "Bãoba-la-lão" e "Noite de São João" que fazem parte de Cantares da infância. Mário de Andrade recebera esse manuscrito, datado de "Junho 1925", junto da carta de 
notáveis, um dos quais pouco ou nada faltava pra ser jóia legítima como poesia isto é lirismo e inteligência construtiva bem equilibrados" ${ }^{23}$.

Do mesmo ano que o da "crítica informal" a Pedro Nava são os comentários que Mário redigiu sobre os poemas em processo de composição de Manuel Bandeira: "Não sei dançar", "Mulheres" e "Pensão familiar". comentários mais detalhados estão na missiva seguinte, de 7 de maio de 1925, dos quais vale destacar o que se refere a "Não sei dançar":

[...] é bem das tais poesias que não são poesia, são lirismo. São pinceladas deliciosas todas, porém eu hoje já estou querendo mais poesia, você sabe. Não aconselho nada a esse respeito, faça o que entender. Mas se você organizasse em forma de rondó já ficava mais construído. E o rondó não é nenhum artifício pois está historicamente provado que é forma popular universal da nossa própria organização psicológica. ${ }^{25}$

Para Mário de Andrade o poema não se caracterizava como poesia, pois o considerou como um agrupamento de sensações de Bandeira. Confirmando sua nova posição sobre "lirismo", debatida inumeráveis vezes com o amigo pernambucano, "aconselha-o" a trabalhar tecnicamente o poema, transformando-o em forma fixa, o rondó.

O ano de 1925 é um momento em que Mário, já tendo bem mais definida sua nova conceituação sobre "lirismo", não tão individualista quanto a primeira, passa a defendê-la, seja em artigos, seja nas trocas de ideias com seus interlocutores. No âmbito das cartas, isso se vê tanto nos "conselhos" ${ }^{26}$ aos jovens escritores como nas conversas com aqueles que estão no mesmo nível de produção que ele, como o amigo Manuel Bandeira. A seguir, está o esclarecimento que Mário fez a ele sobre sua definição de "obra-de-arte", pautado em comentários que o amigo lhe remetera sobre sua Estética musical, que naquela época estava também em processo de elaboração:

22 ...Pedro Nava de 3 de julho de 1925. A carta de Pedro Nava está no acervo Mário de Andrade, no Instituto de Estudos Brasileiros, série Correspondência, sub-série Correspondência Passiva (MA-C-CPL, 5414).

23 ANDRADE; ANDRADE. Carlos E Mário: Correspondência completa entre Carlos Drummond de Andrade e Mário de Andrade, p. 154.

24 Esses poemas foram publicados no livro Libertinagem, em 1930.

25 ANDRADE; BANDEIRA. Correspondência Mário de Andrade \& Manuel Bandeira, p. 206.

26 Sobre o papel de "mentor" de Mário de Andrade e a correspondência trocada entre ele e jovens escritores, ver MORAES, O orgulho de jamais aconselhar. 
Eu estou escrevendo uma Estética musical em que, além da parte normativa, a parte verdadeira do livro, fundada em noções adquiridas por meio de laboratórios e da lição histórica, tem uma introdução puramente ideal, concepcional, em que eu explico minhas idéias pessoais a respeito de Estética, Belo, Arte, Música e Manifestação artística, cinco capítulos que a crítica tem de observar, como verdades humanas e transitórias que são, sob o ponto de vista concepcional do autor, sob o ponto de vista da fecundidade humana que essas idéias contenham e não sob o ponto de vista filosófico, possivelmente científico que elas na realidade não têm, pois que não é ciência no sentido positivo da palavra. ${ }^{27}$ Você discute o meu modo de encarar e dar o conceito (meu) de manifestação artística. Antes de tudo o que você chama de manifestação artística é o que eu chamarei de realização de obra-de-arte ou psicologicamente: concretização artística do lirismo. [...] A obra de arte realizada e desaparecida deixa praticamente de existir. A intenção dela (na infinitiva maioria pela arte do séc. XIX), o que eu chamo na minha Estética de mensagem-do-amigo ficou prejudicada e a manifestação artística não se deu porque a mensagem-do-amigo não foi revelada. A obra-de-arte é construída pra interessar. Sempre. Até no caso ignóbil do sujeito que faz um poema pra si mesmo. [...] Insisto cada vez mais na minha opinião: a manifestação artística só se dá quando a obra-de-arte chegou ao destino a que foi destinada. Pense e me responda. ${ }^{28}$

Em primeiro lugar, deve ser chamada a atenção para o fato de Mário de Andrade explicar que não fundamentou certas noções defendidas na

27 Para efeito de esclarecimento sobre a elaboração dessa obra, é importante transcrever aqui a nota de Marcos Antonio de Moraes na edição da correspondência entre esses dois intelectuais: "Pensada inicialmente como 'lições' semanais de estética para um 'grupo de moças da [...] alta sociedade', alunas do Conservatório Dramático e Musical de São Paulo, e redigida sob forma de conferências, para que MA enfrentasse a sua 'péssima faculdade de elocução', como explica o escritor a Luís da Câmara Cascudo em carta de 26 de março de 1926, a Estética musical chegou a receber 6 capítulos ('Da estética', 'Do belo', 'Da arte', 'Da música', 'Da manifestação musical', 'Do ritmo') dos 10 planejados. Flávia Camargo Toni, na edição anotada que organizou da Introdução à estética musical (São Paulo, Hucitec, 1995), a partir do texto inédito conservado por MA e cadernos de alunas do escritor, mostra que o trecho do estudo enviado a $\mathrm{MB}$, em "primeiríssima redação', não guarda semelhanças com o texto em sua última redação conhecida.” (ANDRADE; BANDEIRA, Correspondência Mário de Andrade E Manuel Bandeira, p. 223, nota 90.)

28 ANDRADE; BANDEIRA. Correspondência Mário de Andrade E Manuel Bandeira, p. 222. Carta de 26 de julho de 1925. 
Estética musical em um ponto de vista filosófico, mas em suas ideias pessoais, que desenvolveu empiricamente. Nota-se, também, que Mário de Andrade está então consolidando sua postura em relação à necessidade da utilização da técnica. Em sua definição de "obra-de-arte", esta não poderia prescindir de uma técnica que tornasse a manifestação lírica aprazível ao leitor. Se estabelecermos aqui uma relação entre essa ideia e o que ele compreendia naquele momento por elaboração poética, teremos o seguinte: a transposição direta do impulso lírico na construção de um poema não se sustentaria mais enquanto obra-de-arte, esta somente se configuraria a partir do momento em que esse impulso fosse elaborado pela técnica.

Nessa fase de sua trajetória na conceituação de "lirismo", entre os inúmeros aconselhamentos que dava aos jovens, encontram-se os diálogos com outro escritor, Prudente de Moraes, neto, assim como Nava, um poeta bissexto. Na carta de 3 de outubro de 1925 está mais um importante esclarecimento de Mário de Andrade sobre o assunto. Nela, Mário comenta poema inédito ${ }^{29}$ que o jovem lhe enviara. O trecho transcrito é extenso, pois vale como importante documento desse processo de construção conceitual de "lirismo" que trilhava Mário de Andrade.

Releio carta e versos pra esta resposta. Por ordem: Versos. Nome pro poema é difícil. São versos deliciosos franqueza. Eu tirava o o definindo "meu corpo" no 7o verso. Não tenha medo que fique um alexandrino perfeito. O alexandrino em si já é um ritmo pesado que dá bem a sensação do cansaço que você está descrevendo. [...] O fim ironicamente reflexivo está muito gostoso. Outro dia recebi do Luís da Câmara Cascudo três poemas descritivos que me deram essa mesma sensação embora um pouco malfeitos, meio apressados. [...] Essa história da intenção de fazer uma poesia é uma coisa muito importante sob o ponto de vista Arte, fazer de deveras arte. Convido você a meditar muito nisso. Tem sido uma das preocupações grandes de minha vida. A "intenção do poema" constrói

29 Na série Manuscritos de outros escritores do arquivo Mário de Andrade, no IEBUSP, constam três poemas de Prudente de Moraes, neto: "Suicídio", "A cachorra" e o poema sem título, com o incipit: "Cansaço nas estradas poeirentas". Este último, que permaneceu inédito, é o que Mário de Andrade está comentando no trecho da carta acima transcrito. No catálogo dessa documentação os manuscritos receberam, respectivamente, os seguintes códigos: MA-MOE, 242; MA-MOE, 243; MA-MOE, 244. Ver MACHADO, Manuscritos de outros escritores no arquivo Mário de Andrade. 
o poema fechado, o poema circunferência, o poema que tem começo tem meio e fim. É mais arte que esse sensacionalismo verdadeiramente primitivistico [sic] como essência em que toda gente modernista caiu mais ou menos. Principalmente os cuja criação vai de dentro pra fora, intimistas, os que se preocupam mais com a sensação que com a causa da sensação, Manuel, Ribeiro Couto eu muitas vezes. Rarissimas [sic] Ronald e Guilherme, naturezas artísticas mais bem construídas e completas. Falo natureza artística no sentido de equilíbrio das faculdades líricas e construtivas. Em Manuel por exemplo, que é o mais cheio de lirismo da minha geração (os que estão agora na casa dos trinta) tem um desequilíbrio evidente entre o lírico e o poeta. Ele mesmo reconhece isso. Todos os últimos poemas dele, desde o Ritmo dissoluto, com algumas excepções apenas, são fragmentos do lirismo constante da vida. São fragmentos completos em si que não tem [sic] nada que falte nem antes nem depois porém são fragmentos porquê [sic] lhes falta o juízo exclusivo do resto e conclusivo da sensação, que lhes daria a intenção de poema, torná-los-ia residentes em si mesmos e não na continuidade da sensação. Me compreende bem? Reflita sobre isso, vale a pena. O poema de você é assim, um fragmento completo. Deus me livre de querer que você vá agora metrificar o poema que fez, está bem como fez porem [sic] não vejo outra solução pra este meu problema que metrificando o Lirismo. A metrificação em si faria a intenção do poema, tornava essas sensações fragmentárias completas residentes nelas mesmas.

Mário deu prosseguimento a sua reflexão nessa longa carta; entretanto, foi selecionada essa passagem para que seja possível evidenciar como, além do que publicava em livros, por meio da "crítica informal" ia esclarecendo sua conceituação de "lirismo" aos colegas. Nesse trecho, ele fez menção a três poemas de Câmara Cascudo, provavelmente os que ele lhe enviara junto da carta de 4 de setembro de $1925^{31}$

No dia seguinte ao da redação desta carta, Mário escreveu para Bandeira, recuperando o que havia falado para Prudente de Morais, neto, e reforçando sua posição sobre "lirismo". Novamente, um trecho longo se faz necessário:

30 ANDRADE. Cartas de Mário de Andrade a Prudente de Moraes, neto, p. 118120.

31 CASCUDO; ANDRADE. Câmara Cascudo e Mário de Andrade: cartas 19241944. 
Sobre o lirismo de você, ontem, inda fiz consideração numa carta pro Prudentinho. Também acho que você é mais lírico que poeta nesse sentido em que a construção de você é puramente organizada dentro da própria sensação e não por meio duma reação intelectual reflexiva sobre a matéria lírica a empregar e conclusiva quanto à separação da matéria lírica empregada, das sensações permanentes da vida, anteriores e posteriores ao momento lírico que você fixa no poema. Se lembra do prefácio do Losango cáqui? Falta enfim a uma quantidade de poemas tanto de você quanto duma porção de outros entre nós (eu especialmente no Losango e por isso os poemas vêm numerados) a intenção de poema, de fazer uma coisa fechada. Em você o lirismo ultrapassa de muito a riqueza, a faculdade de construção (intelectual). Não de construção dos versos em si, porém de construção dos poemas, isto é, duma coisa que deve ser fechada, que tem princípio, meio e fim! Esse, aliás, é um dos problemas que mais me tem preocupado desde os tempos do Losango cáqui. Muitos dos nossos poemas são fragmentos do sensacionismo lírico cotidiano, fragmentos completos em si, é lógico, fragmentos que não têm nada que ver com o sensacionismo anterior ao de que eles derivam, nem com o posterior, mas porém não deixam de ter essa essência fragmentária que você raramente encontrará na poesia anterior ao simbolismo. Será um dos encantos do lirismo desde o simbolismo, não discuto, porém o simbolismo e principalmente Samain quase sempre em poemas intimistas assim metrificavam e rimavam, isto é, poetizavam. A poética era pra eles o que encerrava (e muito bem) o poema dentro de si mesmo. A utilização de ritmos livres veio tirar essa organização intelectual poética que o pós-simbolismo tinha quase sempre. E o problema ficou a espera de resolução. Eu tenho tentado algumas, metrificando, dando cortes estróficos especiais facilmente perceptíveis e usando a forma popular do rondó. Ainda não estou satisfeito, embora todas essas formas me satisfaçam. Isto é, não é bem que não esteja satisfeito, ainda não me acalmei é que quero falar. ${ }^{32}$

As conceituações de "lirismo", que Mário foi construindo ao longo de sua vida, são apenas uma parte de um projeto muito maior. Provavelmente, de formação de um novo movimento literário com base intelectual sólida. Por esse motivo, talvez, ele tenha tomado a frente de um grupo que intentava a renovação da intelligentsia brasileira, tenha passado todo o tempo buscando definir teoricamente as inovações modernistas e tenha se dedicado irrestritamente

32 ANDRADE; BANDEIRA. Correspondência Mário de Andrade E Manuel Bandeira, p. 242. Carta de 4 de outubro de 1925. 
ao diálogo epistolar, por meio do qual disseminava suas ideias, estimulava a reflexão e sua circulação entre aqueles que se aproximavam das propostas modernistas.

Ainda no correr da segunda metade da década de 1920, continuaram os diálogos sobre "lirismo", como na resposta que escreveu a Carlos Drummond de Andrade sobre os comentários que este fizera a Losango cáqui, que acabara de sair da gráfica:

Sua carta sobre o Losango é boa mesmo. Quero bem ela. Sobre intelectualidade poética discutirei se me lembrar quando tiver tempo. Estou cada vez mais convicto que carece botar inteligência (sentida) na poesia. Meus poemas são cada vez mais pensados. Discutiremos. Não sei se é a infecundidade que vem. Tenho medo de dar em poeta brasileiro. Porém não me parece por enquanto. Tudo retumba tanto em mim! ! $^{33}$

Em 1928, sobre novos poemas que estava elaborando, Mário estabeleceu novo diálogo com Bandeira: "Porque me parece que fiz dois poemas (fase nova, a tal inglesícica) bem bonzinhos. Um já corrigido, 'Bodas montevideanas', inspirado no caso Germana-Vignale, outro 'Adivinha' ${ }^{34}$ inda só no primeiro escrito. A idéia me parece forte e original no possível".

Atendendo à solicitação do amigo - "Mande os poemas, estou cheio de curiosidade" ${ }^{36}$-, Mário enviou os manuscritos junto com a carta em que esclarece o processo de invenção que os envolveu. Mais uma vez, é necessária a transcrição de um longo trecho:

Você mandou pedir e mando os versos. Que vão! Afinal eu devia mesmo esse sacrifício como prova de amizade... Porque é engraçado o que eu sinto comigo, uma espécie de fatalidade dolorosa de escrever assim, sem a mínima pretensão de escrever verso, sem a mínima intenção de fazer poesia. Jamais como agora e como nesses versos eu tive tanto a despreparação para poesia. Jamais como com eles não se deu aquele juízo que a gente tem tantas vezes: vamos fazer uma poesia. Saíram por

33 ANDRADE; ANDRADE. Correspondência completa entre Carlos Drummond de Andrade e Mário de Andrade, p. 194. Carta de 18 de fevereiro de 1926.

34 Esses dois poemas foram publicados em Remate de Males, de 1930.

35 ANDRADE; BANDEIRA. Correspondência Mário de Andrade \& Manuel Bandeira, p. 374. Carta de Mário de Andrade, de 21 de janeiro de 1928.

36 ANDRADE; BANDEIRA. Correspondência Mário de Andrade E Manuel Bandeira, p. 376. Carta de Manuel Bandeira, de 25 de janeiro de 1928. 
uma necessidade essencial de sair. Parece incrível. Porém eu era incapaz de medir pra você. Agora veja a contradição misteriosa e que me parece irresolvível: tão dentro do conceito de lirismo e tão organizados (portanto poesia) que foram eles e no entanto possivelmente tão pouco bons e tão pouco poesia!... Porque estou na incapacidade total de julgar essas coisas e o juízo dos outros não me satisfaz. Está claro que muito matutando sobre poesia e sobretudo não me satisfazendo mais nem o verso livre nem aquele exteriorismo representativo que caracterizou o que de melhor deu a poesia modernista entre nós, todos esses pensamentos haviam mesmo de atuar fundo na minha pesquisa formal, no meu processo de realização de poética ideal e nos motivos de inspiração do meu lirismo, está claro. Porém tudo isso ficou agindo sem intenção nestes poemas que vão agora. Não tive intenção raciocinada. Essa eu tive por exemplo na "Vitória-régia" fiz o poema intencionalmente dentro duma tese e discuti a tese com você e com o Couto $^{37}$ e depois desfiz o poema como você me aconselhou, fiz dele a prosa, um dos dias do diário do "Turista Aprendiz". Com estes poemas não, e é certo pelas datas se percebe que saíram quando quiseram sair. Portanto o título de experiências não me satisfaz sobre eles. [...] Já creio que falei pra você: gosto deles, acho que são meus e lindos e se uma crítica alheia como a de você pode me esclarecer alguma coisa só por isso mesmo é que reconheço a possibilidade e a necessidade dela. Porém nenhuma crítica alheia nem a de você que é mesmo uma reza de amizade poderá me tirar da minha realidade: que os poemas são bons. Mas eis a miséria: é que os poemas, estes, muito menos individualistas na forma e no pensamento geral atingiram o máximo de individualismo, já não podem mais interessar ninguém senão eu. E fico na contradição mais amargamente irônica de minha vida: eu, que não me interesso mesmo por mim, que se escrevo é mesmo porque quero amor e aplauso dos outros, sempre amor, estou escrevendo poemas e pra isso e só isso e os poemas saem meus e só pra mim. Minha inquietação agora atingiu uma grandeza verdadeiramente trágica e minha vida interior está transformada num delírio. ${ }^{38}$

Bandeira respondeu às angústias de Mário em carta "longa", comparada ao seu estilo sucinto de missivista. Inicia de forma jocosa as impressões sobre os poemas, sem validar as preocupações do amigo:

37 Provavelmente Rui Ribeiro Couto ou Antonio Carlos Couto de Barros.

38 ANDRADE; BANDEIRA. Correspondência Mário de Andrade \& Manuel Bandeira, p. 376-377. Carta de 30 de janeiro de 1928. 
Você é engraçado: escreve uns poemas com os quais "vibra internamente muito", e ainda tem o desplante de chicanar sobre eles, só porque imagina que eles não poderão interessar a ninguém! Ora, Mário, vai te foder. Deixe de inventar tragédias onde só existe vida gozada. Não há nada melhor do que fazer um poema e "vibrar internamente muito com ele". O único meio digno, o único meio decente de interessar os outros é esse: vibrar internamente muito com a coisa que se está fazendo. Isto o que a gente deve buscar primeiramente, e tudo o mais será acrescentado.

Depois os poemas estão individualíssimos (desde Paulicéia você não é tão individual) mas não me parece que sejam individualistas. Ao contrário me parecem tão preocupados pelos outros, pela felicidade dos outros, pelo amor do gênero...

Na sequência comenta os poemas:

Sobre os poemas direi, para lhe satisfazer a vontade, que como poema só não me satisfaz a "Louvação matinal", neste sentido que não me parece poesia nem verso. É uma meditação filosófica em prosa. Muito bonita aliás. É uma linda perspectiva de pensamento num alto e tranqüilo movimento rítmico de prosa, não tem o elemento lírico da poesia; não tem o elemento musical do verso. [...] Os outros três ("Bodas", "Ponteado" e "Adivinha") são os melhores. Boiei completamente na "Adivinha". Macacos me mordam se entendi aquilo. Mas essa mesma incompreensão suscita em mim o estado lírico, e o refrão "que é que é" é formidável como elemento rítmico e organiza imperiosamente todo o contexto.

Bandeira conclui suas impressões sobre os poemas tocando num assunto muito importante naquele momento, que era o emprego de uma língua brasileira moderna que Mário de Andrade fazia em seus textos. Aliás, na segunda metade da década de 1920, esse assunto aparece mais presente nas cartas do que o "lirismo". Vale apenas destacar que Bandeira chama atenção sobre a individualidade de Mário de Andrade:

Nestes poemas você me dá a impressão de se ter renovado e neles a sua personalidade se acusa menos por maneiras de expressão, por tics

39 ANDRADE; BANDEIRA. Correspondência Mário de Andrade E Manuel Bandeira, p. 379. Carta de 4 de fevereiro de 1928.

40 ANDRADE; BANDEIRA. Correspondência Mário de Andrade \& Manuel Bandeira, p. 379. 
que fizeram você desgraçadamente tão imitável, do que pelas idéias e sentimentos. Se eu tivesse sanção sobre você, obrigá-lo-ia a tirar da sua linguagem o que a está assinalando como sua e os outros arremedam. Nisso é que você é escandalosamente, condenavelmente individualista. ${ }^{41}$

O prosseguimento dessa discussão, se realmente houve por cartas, não foi preservado. Por fim, veremos mais uma menção à questão do "lirismo", esta já no final da década de 1920. Ela está na carta de Mário de Andrade a Manuel Bandeira, de 13 de julho de 1929. E vale muito como uma síntese do sentimento desse intelectual a respeito de sua trajetória de conceituação sobre esse tema ao longo dos anos 20. A declaração de Mário nesta carta foi provocada pelo comentário de Bandeira sobre "Poemas da negra", série de poemas inéditos naquele momento, que sairiam no ano seguinte em Remate de males:

Prudentinho me convocou para ler os "Poemas da negra". Fui ao escritório dele. Leitura muito afobada cortada de conversas e da presença nervosa de Iná. Não posso falar desses poemas. Não os senti, quero dizer não experimentei emoção artística, salvo quando você fala no "prazer de se reconhecer em naturezas-mortas". Sinto isso intensamente no per amica etc. de minha casinha silenciosa (deliciosa esta brincadeira da sua carta). Mas não tenho nada a dizer como crítica dos poemas. Não posso dizer que não gosto, ou que não gosto disto ou daquilo. ${ }^{42}$

Na resposta de 13 de julho, então, a síntese:

Quanto à evolução poética, é bem terrível a gente ser evolucionista! Você ponha reparo só no mundo de versos inéditos que tenho, de que você conhece apenas metade, se tanto! e que são o que já não sou mais. É doloroso, palavra. Escrevo demais. Jogo sessenta por cento fora e o resto inda dá pra publicar uns três livros por ano, é fantástico. Isso me desgosta bem. E já não são mais eu, pelo menos no meu eu permanente, o que subsiste através de todas as minhas mudanças... O eu atual é o dos "Poemas da negra" e do "Crepúsculo", deste eu não gostando absolutamente nada.

41 ANDRADE; BANDEIRA. Correspondência Mário de Andrade E Manuel Bandeira, p. 379.

42 ANDRADE; BANDEIRA. Correspondência Mário de Andrade E Manuel Bandeira, p. 426.

43 Segundo nota de Marcos Antonio de Moraes na edição dessas cartas, "Crepúsculo" foi publicado em Costela do grã cão, com o título "Momento" e 
Foi como amostra apenas. Estou atingindo, Manu, acho que o cume da minha invisibilidade. E é nisso que estamos atualmente no máximo de separação: você todo sensibilidade, todo impulsivo, eu cada vez mais recatado, mais artíficie, mais principalmente invisível. E me compreendo na minha invisibilidade. Porque por outro lado meus versos tocam o oposto do surrealismo. ${ }^{44}$

Ao que parece, o estado de angústia confessado a Manuel Bandeira na época da composição de Losango cáqui não foi amenizado ou pode ter-se transformado. Pelo que as cartas demonstram, a invenção poética de Mário de Andrade teve que ser sempre pautada em seus estudos teóricos e isso fez com que ele se distanciasse cada vez mais da forma individualista de fazer poesia apresentada em Pauliceia desvairada. Mário de Andrade passou a se opor àqueles que mantiveram tal postura, como fez Oswald de Andrade, por exemplo. Mário, nesse tempo, seguia já em outro rumo, interessando-se pela "arte-de-ação". Ainda nessa carta, finalmente, conclui:

É certo que meus versos são todos impulsivos. É falso que jamais eu tenha escrito um só verso (Mesmo dos que me parecem falsos atualmente) pra provar ou botar em prática uma teoria minha. Mas estas teorias existiam de antemão. E na verdade foi pela preocupação intensa delas que a maioria dos meus versos saiu, como diz Augusto Meyer, exemplos quase didáticos de Poética. Muito menos versos do que exemplos. Aliás minha doutrina de fazer arte-de-ação inda comprova isso, arte que levasse os outros pra certas coisas e que lhes permitisse fazer melhor que eu. O que me interessava mais era animar.

Nessa definição de "arte-de-ação", enquadra-se seu projeto de "abrasileiramento" da língua portuguesa, que foi exaustivamente debatido com seus interlocutores. As discussões sobre "lirismo" não se esgotam no que foi apresentado até aqui. Pelo contrário, elas se distribuem fartamente pelas correspondências entre Mário de Andrade e seus interlocutores.

43 ... já bastante modificado em comparação com o manuscrito que mandara nessa época a Manuel Bandeira. (ANDRADE; BANDEIRA, Correspondência Mário de Andrade E Manuel Bandeira, p. 419, nota 14)

44 ANDRADE; BANDEIRA. Correspondência Mário de Andrade \& Manuel Bandeira, p. 427-428.

45 ANDRADE; BANDEIRA. Correspondência Mário de Andrade \& Manuel Bandeira, p. 429. 


\title{
Lyricism in epistolary debate Modernist
}

\begin{abstract}
The exchange of letters among the Brazilian modernists was responsible for the circulation of unpublished works and theoretical debates on literary modernism, establishing nets of literate sociability and aesthetic and political consensus. This work aims to study the topic lyricism discussed in the correspondence of Mário de Andrade with some of his interlocutors during the 1920s.
\end{abstract}

Keywords: Lyricism, Brazilian Modernism, Epistolography.

$$
\text { Referências }
$$

ANDRADE, Mário de. A escrava que não é Isaura. In: Obra imatura. 2 ed. São Paulo, Brasília: Martins, INL, 1972.

ANDRADE, Mário de. Correspondente contumaz: cartas a Pedro Nava 1925-1944. Rio de Janeiro: Nova Fronteira, 1982.

ANDRADE, Mário de. Cartas de Mário de Andrade a Prudente de Moraes, neto. Organização Georgina Koifman. Rio de Janeiro: Nova Fronteira, 1985.

ANDRADE, Mário de; BANDEIRA, Manuel. Correspondência Mário de Andrade G Manuel Bandeira. Organização, introdução e notas Marcos Antonio de Moraes. 2 ed. São Paulo: Editora da Universidade de São Paulo, 2001.

ANDRADE, Mário de; ANDRADE, Carlos Drummond de. Carlos E Mário: correspondência completa entre Carlos Drummond de Andrade e Mário de Andrade. Organização e pesquisa iconográfica Lélia Coelho Frota, prefácio e notas Silviano Santiago. Rio de Janeiro: Bem-te-vi, 2003.

CASCUDO, Luís da Câmara; ANDRADE, Mário de. Câmara Cascudo e Mário de Andrade: cartas 1924-1944. Pesquisa documental, iconográfica, estabelecimento de texto de notas (organizador) Marcos Antonio de Moraes; ensaio de abertura Anna Maria Cascudo Barreto; prefácio Diógenes da Cunha Lima; Introdução Ives Gandra da Silva Martins. São Paulo: Global, 2010.

MACHADO, Marcia Regina Jaschke. Manuscritos de outros escritores no arquivo Mário de Andrade: perspectivas de estudo. São Paulo: Linear B, Faculdade de Filosofia, Letras e Ciências Humanas, USP, 2008.

MORAES, Marcos Antonio de. O orgulho de jamais aconselhar a epistolografia de Mário de Andrade. São Paulo: Editora da Universidade de São Paulo, Fapesp, 2007.

SCHWARZ, Roberto. O psicologismo na poética de Mário de Andrade. In: A sereia e o desconfiado. 2 ed. Rio de Janeiro: Paz e Terra, 1981. p. 13-23. 